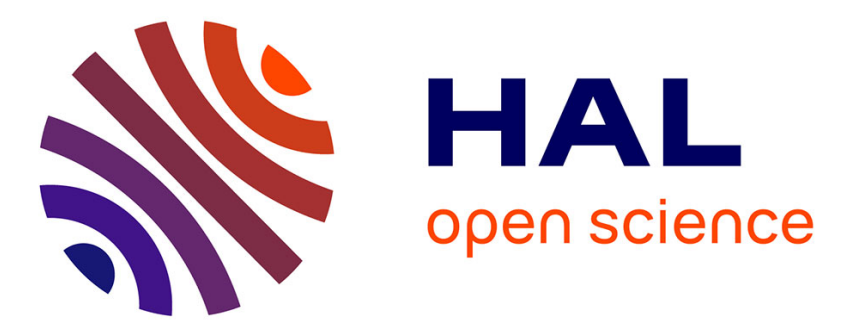

\title{
Neutral carbohydrate geochemistry of particulate material (trap and core sediments) in an eutrophic lake (Aydat, France)
}

\author{
S. Ogier, Jean-Robert Disnar, Patrick Albéric, G. Bourdier
}

\section{- To cite this version:}

S. Ogier, Jean-Robert Disnar, Patrick Albéric, G. Bourdier. Neutral carbohydrate geochemistry of particulate material (trap and core sediments) in an eutrophic lake (Aydat, France). Organic Geochemistry, 2001, 32, pp.151-162. 10.1016/S0146-6380(00)00138-8 . hal-00089809

HAL Id: hal-00089809

https://hal-insu.archives-ouvertes.fr/hal-00089809

Submitted on 16 Nov 2006

HAL is a multi-disciplinary open access archive for the deposit and dissemination of scientific research documents, whether they are published or not. The documents may come from teaching and research institutions in France or abroad, or from public or private research centers.
L'archive ouverte pluridisciplinaire HAL, est destinée au dépôt et à la diffusion de documents scientifiques de niveau recherche, publiés ou non, émanant des établissements d'enseignement et de recherche français ou étrangers, des laboratoires publics ou privés. 


\title{
Neutral carbohydrate geochemistry of particulate material (trap and core sediments) in an eutrophic lake (Aydat, France)
}

\author{
Sylvie Ogier ${ }^{\mathrm{a}}$, Jean-Robert Disnar ${ }^{\mathrm{a}}$, Patrick Albéric ${ }^{\mathrm{a}}$ and Gilles Bourdier \\ a UMR 6531 du CNRS “Sédimentation and Diagenèse de la Matière Organique", Université \\ d'Orléans, BP 6759, 45067 Orléans cedex 02, France - remplacé par UMR6113 - ISTO \\ ${ }^{\mathrm{b}}$ Laboratoire de Biologie Comparée des Protistes, (CNRS UA 6023), Université Blaise Pascal \\ Clermont-Ferrand, 63177 Aubière cedex, France
}

\section{Abstract}

Carbohydrate compositions were determined on sinking particles and core samples from eutrophic lake Aydat. Carbohydrate fluxes indicate that phytoplanktonic production is the main organic matter $(\mathrm{OM})$ source whereas the monosaccharides concentrations normalised to OC contents $\left(\mathrm{TCH}_{2} \mathrm{O}\right)$ mostly reflect degradation. The abundance of rhamnose in all samples, its increasing fluxes (together with fucose) with increasing water depth, and its strong decrease in the top $5 \mathrm{~cm}$ of the bottom sediments mark the intense activity of the microbiota. The almost complete removal of sugars in the water and top sediment indicates very little contribution to the preserved OM stock.

Author Keywords: Monosaccharides; Carbohydrates; Sediment traps; Sinking particles; Eutrophic lake; Aydat lake

\section{Introduction}

Polysaccharides are common structural and storage polymers in both aquatic and terrestrial organisms. They represent $20-40 \mathrm{wt} . \%$ of plankton (Parsons et al., 1984), more than $40 \mathrm{wt} . \%$ of bacteria ( Moers et al., 1993), and more than 75 wt.\% of vascular plants ( Moers et al., 1993). In lakes, the great variety of carbohydrate compounds is a consequence both of autochthonous production and degradation of aquatic biota, in addition to inputs of carbohydrates from plants and soils of the surrounding area. Given their abundance in living organisms, their diversity and the ease with which they can be degraded, carbohydrates have potential as tracers of sources and alteration processes in natural waters.

In eutrophic lakes, which have seasonally anoxic bottom waters and permanently reducing sediments, both waters and sediments are the sites of intensive organic carbon production and consumption (Sarazin et al., 1995). In addition to diagenetic transformations, sinking organic matter-rich particles are extensively and selectively degraded during their transit to bottom sediments ( Meyers and Ishiwatari, 1995).

We report here on the carbohydrate composition of trap and core sediments from Aydat lake, a small eutrophic lake located in the French Massif Central. Following the study of fatty acids in some traps (Maurin et Bourdier, unpublished data) and bottom sediments (Stefanova and Disnar, 2000) and the study of amino-acids at the water-sediment interface ( Alberic et al., 1996), the aim of the present work focuses mainly on the sources of the sedimentary OM 
through carbohydrate analysis and on the degradation of these compounds during settling and early diagenesis. The main conclusion is that such a productive medium (primary planktonic production) is also the site for intensive microbial activity. This microbial activity results in partial degradation, and a change in the original compound distribution during settling, even at rather shallow depth $(<15 \mathrm{~m})$.

\section{Experimental}

\subsection{Study site}

Aydat lake is located in the French Massif Central, $25 \mathrm{~km} \mathrm{SW}$ of Clermont-Ferrand, at $825 \mathrm{~m}$ above sea level. It originates from the damming of a small river, La Veyre, by a basaltic flow 7500 years ago. It has a surface area of $6 \times 10^{5} \mathrm{~m}^{2}$ and an average depth of $7.8 \mathrm{~m}$, with a maximum depth of $15 \mathrm{~m}$. The physical (Poulin, 1996) and chemical (Michard et al., in press) annual survey of the lake mainly shows that it is typically eutrophic and develops an anoxic hypolimnion from May to October. Stratification reaches its maximum in September with an oxycline at 4-5 m below the surface, and disappears totally after the overturn in November ( Michard et al., in press). In contrast to the water column, the sediment is permanently anoxic. The permanence of the stratification of the water body between the periods of overturn is proven by the results of the chemical survey ( Sarazin and Michard et al., 2000) and even better, by the continuous recording of the water temperature every $2 \mathrm{~m}$, during the whole study year ( Poulin, 1996). According to this recording, a gale and a high wind perturbed the water column in May and July 1996, respectively. The first one provoked a partial mixing of the water column down to $7 \mathrm{~m}$ and the second one only to $3 \mathrm{~m}$ depth. These observations allow us to stress that contrary to other lakes ( Hicks et al., 1994) or even marine environments ( Cowie and Hedges, 1984), there is no, or very little, sediment resuspension in lake Aydat.

The algal production is dominated by diatoms (Fragilaria crotonensis and Aulacoseira italica) and cyanobacteria (Anabaena andMicrocystis) (Amblard, 1992). The occurrence of a given species at a certain period of anoxia may change from year to year but those cited remain the primary ones (Amblard, 1992). Organic matter mineralization occurs mainly through methane fermentation (ca. 97\%; Sarazin et al., 1995). The sedimentation rate, which was estimated at about $5 \mathrm{~mm}$ per year from ${ }^{210} \mathrm{~Pb}$ determinations (Sarazin et al., 1992), is presently thought to be higher, perhaps as great as $1 \mathrm{~cm}$ per year (Michard et al., in press).

\subsection{Sample collection and storage}

Three sediment traps, not treated with antibiotics, were deployed at depths of 5, 10 and $14 \mathrm{~m}$ in the deepest part of the lake from October 1995 to September 1996. Trap particles were collected monthly by filtration on glass microfibre filters (Watman GF/F diam. $47 \mathrm{~mm}$.).

Core sediments $(\varnothing=12 \mathrm{~cm}$ and length of $45 \mathrm{~cm})$ were taken in the deepest part of the lake, in December 1995, by scuba divers, by insertion of PVC tubes into the sediment. This operation was done very carefully in order to prevent any disturbance of the upper part of the sedimentary column where the water content is very high (98\% at the sediment surface; $92 \%$ at $40 \mathrm{~cm}$ depth). The core was immediately extruded from the sleeve and split into 22 two cmthick slices. 
All these bulk samples (from traps and core) were weighed, frozen for transportation and freeze-dried in the laboratory. Most of the inorganic material is amorphous silica of diatom origin (i.e. $70-80 \% \mathrm{SiO}_{2}$ ) (Sarazin and Ogier, 1999).

\subsection{Chemical analyses}

\subsubsection{Organic carbon analysis (OC\%)}

The suspended particles on glass microfibre filters $(\mathrm{GF} / \mathrm{F})$ were analysed for organic carbon (OC) by combustion in a LECO CNS 2000 analyser whereas core sediment samples were analysed by Rock-Eval pyrolysis (Espitalié et al., 1985), with an RE6 device of Vinci Technologies.

\subsubsection{Monosaccharide analysis}

The procedure used for neutral sugar analysis is derived from previous works (Modzeleski; Oades et al., 1970; Bethge and Cowie) but mostly from Sigleo (1996). However, because there is much variation in the type and concentration of the acid used for polysaccharide hydrolysis, we first conducted a series of experiments to determine the optimum acid concentration, i.e. a concentration sufficient to release the maximum amounts of compounds but with minimal degradation and/or polycondensation, e.g. Maillard reactions with amino acids. Because of insufficient quantities of sediment trap material (and rather low sugar concentration in the core sediments) this preliminary check was carried out with purified OM from a recent cyanobacterial mat from the Atoll of Mururoa ( Disnar and Trichet, 1980). The results of this test which was carried out in the operating conditions described below for the first hydrolysis step, are presented in Table 1. In contrast to Sigleo (1996), who already observed a notable decrease of sugars released by hydrolysis of river colloidal material with increasing acid concentration from 0.5 to $1 \mathrm{~N}$ (at $100^{\circ} \mathrm{C}$ ), we obtained very comparable yields with $1,1.2$ and $2.5 \mathrm{~N} \mathrm{HCl}$, at $100^{\circ} \mathrm{C}$, at least for compounds present at levels higher than 1 $\mathrm{mg} / \mathrm{g}$. For these compounds, the mean standard error is lower than $7 \%$. It is lower than $4 \%$ for glucose which is present at levels higher than $10 \mathrm{mg} / \mathrm{g}$. According to these results we carried out polysaccharide hydrolysis with a $1.2 \mathrm{~N} \mathrm{HCl}$ concentration. However, we independently determined that $0.5 \mathrm{~N} \mathrm{HCl}$ was sufficient to totally release vascular plant hemicellulosic sugars ( Bourdon, 1999 and Bourdon).

As described below, the hydrolysis was conducted in two successive stages. The first stage aimed to release sugars from rather labile polymers such as hemicelluloses while the second stage, conducted on the solid residue of the first stage, after soaking with concentrated acid, was performed to release especially the cellulosic glucose. As a matter of fact, this pretreatment $(12 \mathrm{~N} \mathrm{HCl})$ is required to hydrate more resilient bonds such as those present in vascular plant cellulose, prior to hydrolysis (Vallentyne, 1963; Cowie and Hedges, 1984). As shown in Tables 2 and 3, glucose is usually dominant or sometimes the only sugar determined in the second hydrolysate $(12 \mathrm{~N} \mathrm{HCl})$. However, xylose is sometimes also determined. In trap samples ( Table 2), xylose is present in relatively small proportions whereas in two core samples (Table 3) it is present in comparable levels to that of glucose (i.e. 5 and $9 \mathrm{~cm}$ ). 
Table 1. Effect of acid strength on labile sugar release from purified OM from a recent cyanobacterial mat (Disnar and Trichet, 1980). Hydrolyses carried out at $100^{\circ} \mathrm{C}$ for $3 \mathrm{~h}$

\begin{tabular}{lrrrrrr}
\hline \multicolumn{7}{c}{$\mathrm{HCl}$ acid concentration } \\
\cline { 2 - 7 } & $0.5 \mathrm{~N}$ & $1 \mathrm{~N}$ & $1.2 \mathrm{~N}$ & $2.5 \mathrm{~N}$ & $4 \mathrm{~N}$ & $5 \mathrm{~N}$ \\
\cline { 2 - 7 } Compounds & & & & & & \\
\hline Arabinose & 0.00 & 0.99 & 0.60 & 0.49 & 0.23 & 0.00 \\
Rhamnose & 2.68 & 5.64 & 6.37 & 6.79 & 4.14 & 3.10 \\
Ribose & 0.00 & 0.18 & 0.00 & 0.19 & 0.51 & 0.00 \\
Fucose & 0.91 & 2.69 & 2.78 & 3.17 & 2.44 & 1.56 \\
Xylose & 3.99 & 6.18 & 6.76 & 5.12 & 2.38 & 1.31 \\
Manose & 1.00 & 4.75 & 5.33 & 5.35 & 4.25 & 2.77 \\
Galactose & 1.05 & 6.37 & 8.03 & 7.50 & 7.61 & 4.80 \\
Glucose & 2.37 & 10.29 & 11.05 & 11.34 & 11.77 & 5.66 \\
Total (mg/g) & 11.99 & 37.08 & 40.92 & 39.95 & 33.32 & 19.20 \\
\hline
\end{tabular}

Table 2. OC content and neutral carbohydrate composition of sediment trap samples

\begin{tabular}{|c|c|c|c|c|c|c|c|c|c|c|c|c|c|c|c|c|}
\hline \multicolumn{7}{|l|}{ Sample } & \multicolumn{10}{|c|}{ Sugar abundance (wt.\%) } \\
\hline Month & $\begin{array}{l}\text { Depth } \\
\text { (m) }\end{array}$ & $\% O C$ & $\begin{array}{l}\text { Bulk flux } \\
\left(\mathrm{g} / \mathrm{m}^{2} \mathrm{~d}\right)\end{array}$ & $\begin{array}{l}O C \\
\text { flux }\end{array}$ & $\begin{array}{l}\text { Sugar flux } \\
\left(\mathrm{g} / \mathrm{m}^{2} / \mathrm{d}\right)\end{array}$ & $\begin{array}{l}\mathrm{TCH}_{2} \mathrm{O} \\
(\mathrm{mg} / 100 \\
\mathrm{mg} \mathrm{OC})\end{array}$ & Arabinose & Rhamnose & Ribose & Fucose & $\begin{array}{l}\text { Xylose } \\
\text { tot. }^{b}\end{array}$ & Xylose $^{\mathrm{c}}$ & Mannose & Galactose & $\begin{array}{l}\text { Glucose } \\
\text { tot. }^{b}\end{array}$ & $\begin{array}{l}\text { Cellulosic } \\
\text { glucose }\end{array}$ \\
\hline $\begin{array}{l}\text { October } \\
24 / 10 / 1995\end{array}$ & $\begin{array}{l}5 \\
10 \\
14\end{array}$ & $\begin{array}{l}25.7 \\
16.7 \\
18.7\end{array}$ & $\begin{array}{l}2.14 \\
3.60 \\
2.54\end{array}$ & $\begin{array}{l}0.55 \\
0.60 \\
0.47\end{array}$ & $\begin{array}{l}0.064 \\
0.028 \\
0.019\end{array}$ & $\begin{array}{l}11.6 \\
4.7 \\
3.9\end{array}$ & $\begin{array}{l}0.5 \\
11.9 \\
4.5\end{array}$ & $\begin{array}{l}37.3 \\
36.0 \\
48.6\end{array}$ & $\begin{array}{l}0.4 \\
6.3 \\
0.0\end{array}$ & $\begin{array}{l}2.1 \\
6.3 \\
7.1\end{array}$ & $\begin{array}{l}6.8 \\
6.3 \\
14.9\end{array}$ & $\begin{array}{l}0.0 \\
0.0 \\
11.7\end{array}$ & $\begin{array}{l}1.1 \\
3.4 \\
2.0\end{array}$ & $\begin{array}{l}0.8 \\
0.0 \\
0.8\end{array}$ & $\begin{array}{l}51.1 \\
29.8 \\
22.0\end{array}$ & $\begin{array}{l}1.6 \\
4.9 \\
3.2\end{array}$ \\
\hline $\begin{array}{l}\text { November } \\
22 / 11 / 1995\end{array}$ & $\begin{array}{l}5 \\
10 \\
14\end{array}$ & $\begin{array}{l}20.6 \\
21.4 \\
23.7\end{array}$ & $\begin{array}{l}3.45 \\
3.57 \\
4.31\end{array}$ & $\begin{array}{l}0.71 \\
0.76 \\
1.02\end{array}$ & $\begin{array}{l}0.082 \\
0.083 \\
0.118\end{array}$ & $\begin{array}{l}11.6 \\
10.9 \\
11.6\end{array}$ & $\begin{array}{l}1.3 \\
0.0 \\
0.0\end{array}$ & $\begin{array}{l}53.6 \\
65.8 \\
59.2\end{array}$ & $\begin{array}{l}0.5 \\
0.0 \\
0.2\end{array}$ & $\begin{array}{l}3.2 \\
20.7 \\
4.5\end{array}$ & $\begin{array}{l}10.1 \\
0.0 \\
5.2\end{array}$ & $\begin{array}{l}6.9 \\
0.0 \\
1.0\end{array}$ & $\begin{array}{l}5.7 \\
0.0 \\
2.1\end{array}$ & $\begin{array}{l}1.8 \\
0.0 \\
1.7\end{array}$ & $\begin{array}{l}23.9 \\
13.5 \\
27.0\end{array}$ & $\begin{array}{l}1.4 \\
1.4 \\
4.2\end{array}$ \\
\hline $\begin{array}{l}\text { December } \\
19 / 12 / 1995\end{array}$ & $\begin{array}{l}5 \\
10 \\
14\end{array}$ & $\begin{array}{l}13.2 \\
13.5 \\
13.5\end{array}$ & $\begin{array}{l}1.35 \\
2.33 \\
2.17\end{array}$ & $\begin{array}{l}0.18 \\
0.31 \\
0.29\end{array}$ & $\begin{array}{l}0.017 \\
0.029 \\
0.028\end{array}$ & $\begin{array}{l}9.5 \\
9.3 \\
9.7\end{array}$ & $\begin{array}{l}3.0 \\
1.3 \\
1.2\end{array}$ & $\begin{array}{l}48.9 \\
42.2 \\
45.6\end{array}$ & $\begin{array}{l}0.4 \\
0.5 \\
0.0\end{array}$ & $\begin{array}{l}9.5 \\
9.7 \\
14.2\end{array}$ & $\begin{array}{l}7.8 \\
5.7 \\
10.0\end{array}$ & $\begin{array}{l}5.7 \\
4.1 \\
7.2\end{array}$ & $\begin{array}{l}3.9 \\
1.5 \\
2.9\end{array}$ & $\begin{array}{l}1.8 \\
1.2 \\
1.3\end{array}$ & $\begin{array}{l}24.7 \\
37.8 \\
24.9\end{array}$ & $\begin{array}{l}11.1 \\
5.7 \\
2.2\end{array}$ \\
\hline $\begin{array}{l}\text { January } \\
23 / 1 / 1996\end{array}$ & $\begin{array}{l}5 \\
10 \\
14\end{array}$ & $\begin{array}{l}8.5 \\
10.2 \\
10.5\end{array}$ & $\begin{array}{l}4.24 \\
4.82 \\
2.18\end{array}$ & $\begin{array}{l}0.36 \\
0.49 \\
0.23\end{array}$ & $\begin{array}{l}0.029 \\
0.025 \\
0.054\end{array}$ & $\begin{array}{l}8.1 \\
5.1 \\
23.5\end{array}$ & $\begin{array}{l}4.2 \\
9.7 \\
5.5\end{array}$ & $\begin{array}{l}37.7 \\
7.9 \\
56.7\end{array}$ & $\begin{array}{l}1.0 \\
0.0 \\
0.2\end{array}$ & $\begin{array}{l}10.4 \\
12.6 \\
24.0\end{array}$ & $\begin{array}{l}28.7 \\
14.2 \\
4.6\end{array}$ & $\begin{array}{l}27.6 \\
5.4 \\
1.7\end{array}$ & $\begin{array}{l}3.4 \\
18.5 \\
0.5\end{array}$ & $\begin{array}{l}1.1 \\
4.5 \\
0.9\end{array}$ & $\begin{array}{l}13.4 \\
32.5 \\
7.7\end{array}$ & $\begin{array}{l}0.0 \\
12.7 \\
1.2\end{array}$ \\
\hline $\begin{array}{l}\text { Febuary } \\
29 / 2 / 1996\end{array}$ & $\begin{array}{l}5 \\
10 \\
14\end{array}$ & $\begin{array}{l}11.8 \\
11.0 \\
11.9\end{array}$ & $\begin{array}{l}5.43 \\
6.33 \\
4.66\end{array}$ & $\begin{array}{l}0.64 \\
0.70 \\
0.55\end{array}$ & $\begin{array}{l}0.032 \\
0.039 \\
0.013\end{array}$ & $\begin{array}{l}5.0 \\
5.7 \\
2.4\end{array}$ & $\begin{array}{l}1.4 \\
2.4 \\
2.2\end{array}$ & $\begin{array}{l}31.9 \\
37.6 \\
45.5\end{array}$ & $\begin{array}{l}0.7 \\
0.0 \\
4.2\end{array}$ & $\begin{array}{l}6.4 \\
21.0 \\
11.1\end{array}$ & $\begin{array}{l}4.2 \\
3.0 \\
10.7\end{array}$ & $\begin{array}{l}0.0 \\
0.0 \\
0.0\end{array}$ & $\begin{array}{l}4.8 \\
1.3 \\
1.5\end{array}$ & $\begin{array}{l}2.4 \\
2.0 \\
0.0\end{array}$ & $\begin{array}{l}48.1 \\
32.7 \\
24.8\end{array}$ & $\begin{array}{l}3.9 \\
3.5 \\
10.3\end{array}$ \\
\hline $\begin{array}{l}\text { March } \\
26 / 3 / 1996\end{array}$ & $\begin{array}{l}5 \\
10 \\
14\end{array}$ & $\begin{array}{l}10.5 \\
10.6 \\
\text { nd }\end{array}$ & $\begin{array}{l}3.93 \\
\mathrm{nd}^{2} \\
\text { nd }\end{array}$ & $\begin{array}{l}0.41 \\
\text { nd } \\
\text { nd }\end{array}$ & $\begin{array}{l}0.027 \\
\text { nd } \\
\text { nd }\end{array}$ & $\begin{array}{l}6.5 \\
\text { nd } \\
\text { nd }\end{array}$ & $\begin{array}{l}4.8 \\
\text { nd } \\
\text { nd }\end{array}$ & $\begin{array}{l}41.3 \\
\text { nd } \\
\text { nd }\end{array}$ & $\begin{array}{l}0.0 \\
\text { nd } \\
\text { nd }\end{array}$ & $\begin{array}{l}13.0 \\
\text { nd } \\
\text { nd }\end{array}$ & $\begin{array}{l}3.3 \\
\text { nd } \\
\text { nd }\end{array}$ & $\begin{array}{l}0.0 \\
\text { nd } \\
\text { nd }\end{array}$ & $\begin{array}{l}2.6 \\
\text { nd } \\
\text { nd }\end{array}$ & $\begin{array}{l}1.3 \\
\text { nd } \\
\text { nd }\end{array}$ & $\begin{array}{l}33.8 \\
\text { nd } \\
\text { nd }\end{array}$ & $\begin{array}{l}3.6 \\
\text { nd } \\
\text { nd }\end{array}$ \\
\hline $\begin{array}{l}\text { April } \\
3 / 5 / 1996\end{array}$ & $\begin{array}{l}5 \\
10 \\
14\end{array}$ & $\begin{array}{l}13.0 \\
13.9 \\
11.1\end{array}$ & $\begin{array}{l}3.31 \\
3.00 \\
7.11\end{array}$ & $\begin{array}{l}0.43 \\
0.42 \\
0.79\end{array}$ & $\begin{array}{l}0.027 \\
0.031 \\
0.049\end{array}$ & $\begin{array}{l}6.3 \\
7.4 \\
6.2\end{array}$ & $\begin{array}{l}3.5 \\
2.1 \\
2.5\end{array}$ & $\begin{array}{l}39.0 \\
46.3 \\
31.1\end{array}$ & $\begin{array}{l}1.3 \\
1.8 \\
1.2\end{array}$ & $\begin{array}{l}11.1 \\
15.3 \\
7.1\end{array}$ & $\begin{array}{l}7.8 \\
13.5 \\
14.2\end{array}$ & $\begin{array}{l}0.0 \\
7.9 \\
12.7\end{array}$ & $\begin{array}{l}6.6 \\
4.8 \\
7.2\end{array}$ & $\begin{array}{l}2.5 \\
1.5 \\
3.8\end{array}$ & $\begin{array}{l}28.2 \\
14.7 \\
33.0\end{array}$ & $\begin{array}{l}7.3 \\
3.0 \\
7.8\end{array}$ \\
\hline $\begin{array}{l}\text { May } \\
29 / 5 / 1996\end{array}$ & $\begin{array}{l}5 \\
10 \\
14\end{array}$ & $\begin{array}{l}12.1 \\
11.7 \\
11.5\end{array}$ & $\begin{array}{l}4.86 \\
7.27 \\
3.86\end{array}$ & $\begin{array}{l}0.59 \\
0.85 \\
0.44\end{array}$ & $\begin{array}{l}0.029 \\
0.030 \\
0.016\end{array}$ & $\begin{array}{l}5.0 \\
3.6 \\
3.6\end{array}$ & $\begin{array}{l}1.1 \\
1.8 \\
3.7\end{array}$ & $\begin{array}{l}46.9 \\
49.8 \\
25.2\end{array}$ & $\begin{array}{l}0.0 \\
0.0 \\
0.8\end{array}$ & $\begin{array}{l}20.8 \\
16.4 \\
5.9\end{array}$ & $\begin{array}{l}8.1 \\
6.6 \\
11.5\end{array}$ & $\begin{array}{l}3.9 \\
1.9 \\
0.0\end{array}$ & $\begin{array}{l}3.0 \\
1.5 \\
8.3\end{array}$ & $\begin{array}{l}1.2 \\
0.9 \\
3.3\end{array}$ & $\begin{array}{l}18.9 \\
22.9 \\
41.4\end{array}$ & $\begin{array}{l}5.8 \\
2.6 \\
11.5\end{array}$ \\
\hline $\begin{array}{l}\text { June } \\
27 / 6 / 1996\end{array}$ & $\begin{array}{l}5 \\
10 \\
14\end{array}$ & $\begin{array}{l}13.4 \\
12.7 \\
10.9\end{array}$ & $\begin{array}{l}4.00 \\
4.60 \\
6.70\end{array}$ & $\begin{array}{l}0.54 \\
0.58 \\
0.73\end{array}$ & $\begin{array}{l}0.045 \\
0.065 \\
0.074\end{array}$ & $\begin{array}{l}8.5 \\
11.2 \\
10.1\end{array}$ & $\begin{array}{l}1.7 \\
0.0 \\
1.4\end{array}$ & $\begin{array}{l}53.2 \\
59.9 \\
55.0\end{array}$ & $\begin{array}{l}0.0 \\
0.0 \\
0.0\end{array}$ & $\begin{array}{l}22.9 \\
30.6 \\
29.9\end{array}$ & $\begin{array}{l}5.1 \\
3.3 \\
5.1\end{array}$ & $\begin{array}{l}1.6 \\
0.0 \\
3.8\end{array}$ & $\begin{array}{l}1.7 \\
0.2 \\
0.0\end{array}$ & $\begin{array}{l}1.0 \\
0.0 \\
0.0\end{array}$ & $\begin{array}{l}14.4 \\
6.0 \\
8.5\end{array}$ & $\begin{array}{l}1.8 \\
1.6 \\
4.4\end{array}$ \\
\hline $\begin{array}{l}\text { July } \\
27 / 7 / 1996\end{array}$ & $\begin{array}{l}5 \\
10 \\
14\end{array}$ & $\begin{array}{l}13.4 \\
11.5 \\
12.0\end{array}$ & $\begin{array}{l}2.10 \\
3.38 \\
3.31\end{array}$ & $\begin{array}{l}0.28 \\
0.39 \\
0.40\end{array}$ & $\begin{array}{l}0.017 \\
0.019 \\
0.028\end{array}$ & $\begin{array}{l}5.9 \\
4.9 \\
7.1\end{array}$ & $\begin{array}{l}0.9 \\
0.9 \\
4.2\end{array}$ & $\begin{array}{l}33.8 \\
46.5 \\
46.2\end{array}$ & $\begin{array}{l}0.3 \\
3.1 \\
0.0\end{array}$ & $\begin{array}{l}14.7 \\
15.5 \\
26.1\end{array}$ & $\begin{array}{l}2.8 \\
17.5 \\
5.5\end{array}$ & $\begin{array}{l}0.0 \\
0.0 \\
4.0\end{array}$ & $\begin{array}{l}4.1 \\
3.3 \\
1.9\end{array}$ & $\begin{array}{l}3.2 \\
2.8 \\
0.9\end{array}$ & $\begin{array}{l}40.3 \\
10.4 \\
15.3\end{array}$ & $\begin{array}{l}7.2 \\
3.8 \\
4.6\end{array}$ \\
\hline
\end{tabular}




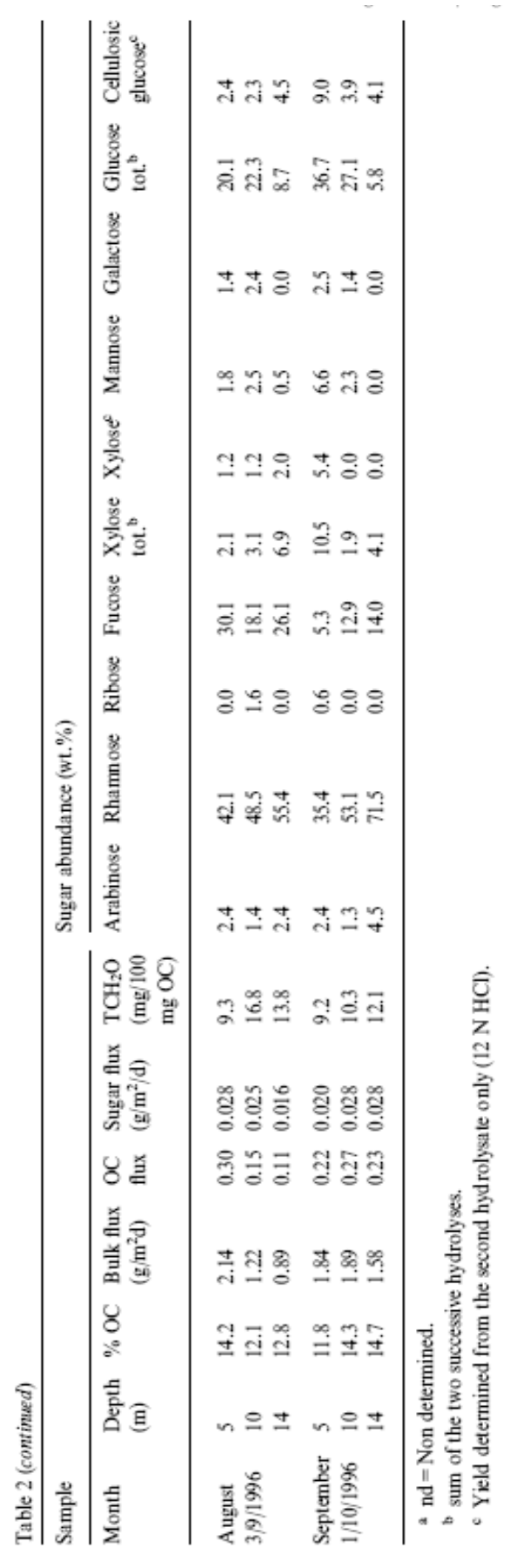


Table 3. OC content and neutral carbohydrate composition of sediment core samples

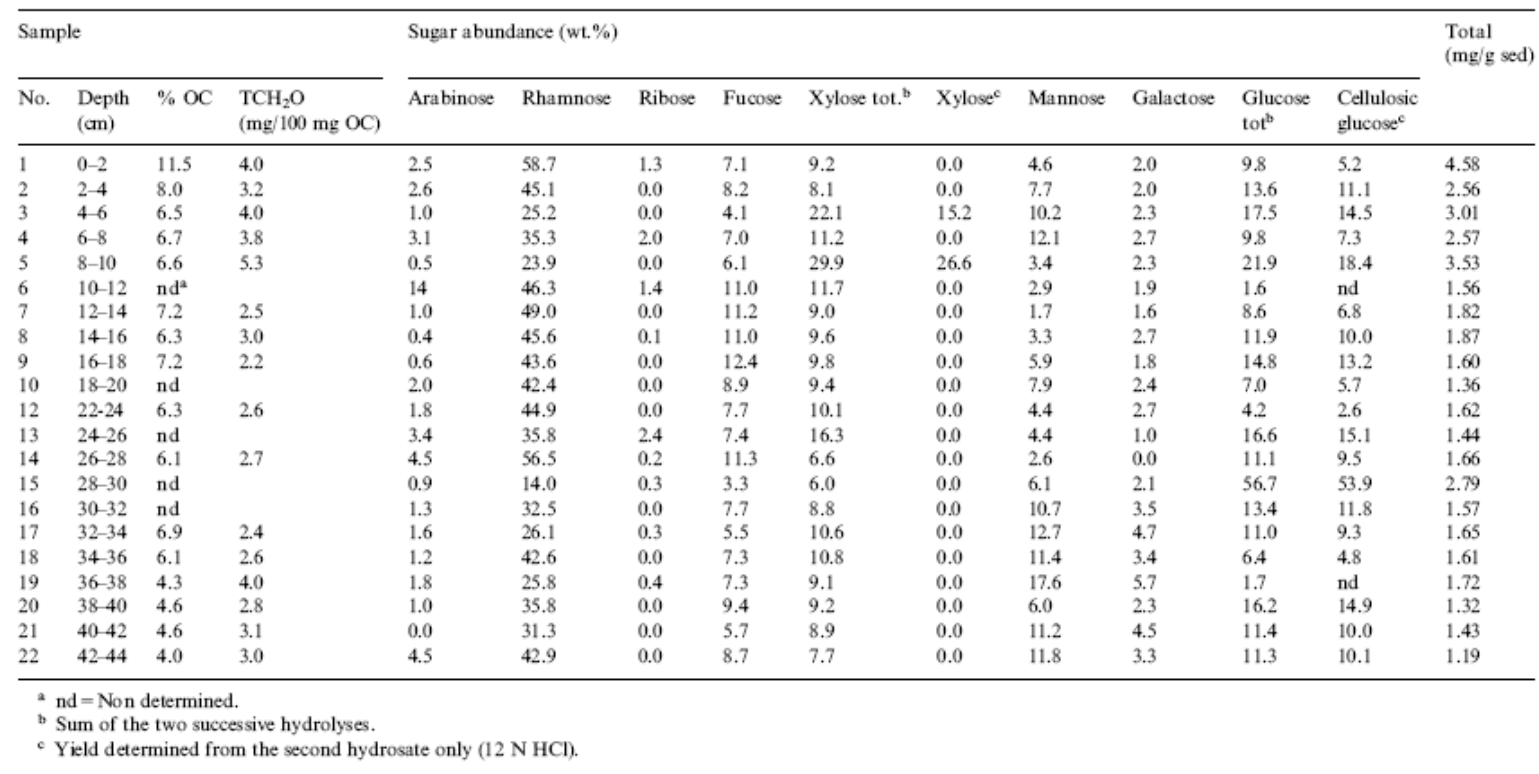

\subsubsection{Operating procedure}

Samples for neutral sugar analysis (1-18 $\mathrm{mg}$ of the material collected on the GF/F filters for trap sediments and $10 \mathrm{mg}$ for core sediments) were introduced in Pyrex tubes together with 5 $\mathrm{ml}$ of $1.2 \mathrm{~N} \mathrm{HCl}$, the tubes were tightly closed under vacuum and heated for $3 \mathrm{~h}$ at $100^{\circ} \mathrm{C}$ in an oven. After hydrolysis and cooling, the samples were filtered on GF/F filters. The solution was kept for sugar analysis while the solid residue and the filter were introduced in Pyrex tubes where they were soaked for $12 \mathrm{~h}$ at ambient temperature with $2 \mathrm{ml}$ of $12 \mathrm{~N} \mathrm{HCl}$. After that stage, the concentrated acid was diluted to $1.2 \mathrm{~N} \mathrm{HCl}$, the tubes were closed under vacuum and the hydrolysis was performed under the conditions described above for the labile sugars. In each hydrolysate, $1 \mathrm{ml}$ of a $0.2 \mathrm{mg} / \mathrm{ml}$ solution of 6-deoxy-D-glucose, was added as an internal standard (Wicks et al., 1991). The hydrolysates were first concentrated to 1-2 ml in a rotary evaporator, at a temperature not exceeding $50^{\circ} \mathrm{C}$. Subsequently, the residual water and acid were evaporated to dryness at $25-30^{\circ} \mathrm{C}$, after the addition of $20 \mathrm{ml}$ of propan-2-ol which forms an azeotrope with $\mathrm{H}_{2} \mathrm{O}$ and $\mathrm{HCl}$. The flasks containing the sugars were dried during $24 \mathrm{~h}$ over $\mathrm{KOH}$ in a desiccator. The anomeric sugar mixtures were equilibrated with 1 $\mathrm{ml}$ of lithium perchlorate $(0.2 \%)$ in pyridine, in closed vials, for $12 \mathrm{~h}$, at $40^{\circ} \mathrm{C}$ (Bethge et al., 1966). Sylilation was performed by adding $0.5 \mathrm{ml}$ of N,OBis(trimethylsilyl)trifluoroacetamide and leaving the vials for $1 \mathrm{~h}$ at $70^{\circ} \mathrm{C}$. The solvent and excess sylilating reagent were removed under reduced pressure, $1 \mathrm{ml}$ of toluene was added and the trimethylsilyl derivatives were analysed by capillary gas chromatography. 


\subsubsection{Capillary gas chromatography}

The silylated sugars were analysed on a Perkin-Elmer Auto System XL gas chromatograph equipped with a CP-Sil 5CB fused silica capillary column $(0.22 \mathrm{~mm}$ i.d. $\times 25 \mathrm{~m} ; 27 \mu \mathrm{m}$ film thickness), a flame ionization detector held at $300^{\circ} \mathrm{C}$, a split/splitless injector maintained at $300^{\circ} \mathrm{C}$ and used in the splitless mode (valve reopened $1 \mathrm{~min}$ after injection). After $1 \mathrm{~min}$ hold at $60^{\circ} \mathrm{C}$ the oven temperature was increased from 60 to $120^{\circ} \mathrm{C}$ at $30^{\circ} \mathrm{C} / \mathrm{min}$, and then from 120 to $240^{\circ} \mathrm{C}$ at $3^{\circ} \mathrm{C} / \mathrm{min}$. The carrier gas was helium. Peaks were identifited (through retention times) and quantified using a standard mixture of eight neutral monosaccharides, namely, arabinose, rhamnose, ribose, fucose, xylose, mannose, galactose and glucose. Quantitation was based on one of the major and better resolved anomer peaks given by each studied compound (Bethge et al., 1966). Total sugars were calculated as the sum of the compounds identified and quantified. Analytical errors, determined from four-fold replicate analyses of the same equilibrated standard solution, varied between 2.6 and $13 \%$ depending on the type and the abundance of the compound considered (rhamnose $=3.1 \%$; RIBOSE $=11.5 \% ; \quad$ FUCOSE $=11.7 \% ; \quad$ XYLOSE $=4.2 \% ; \quad$ MANNOSE $=4.7 \%$; GALACTOSE $=13.1 \%$; GLUCOSE $=10.1 \%$ ). This error is comparable to that determined with the cyanobacterial material used for checking hydrolysis conditions (see above).

\section{Results}

\subsection{Sediment traps}

Bulk particulate material, diatom silica, OC and total carbohydrate fluxes measured on the 12 monthly sediment-trap samples collected at $5 \mathrm{~m}$ depth, in the epilimnion of the lake, display closely parallel temporal variations (Fig. 1). The highest sugar fluxes, which reach 0.082 $\mathrm{g} / \mathrm{m}^{2} / \mathrm{d}$ are observed in November, the month of the lake overturn. Other high values are observed from January to June. Usually sugar fluxes vary similarly in the deepest traps (10 and $14 \mathrm{~m}$ ) and in the epilimnion. Exceptions observed in October, January, May and July at $10 \mathrm{~m}$ depth, and in October and February at $14 \mathrm{~m}$ (Table 2) are discussed later.

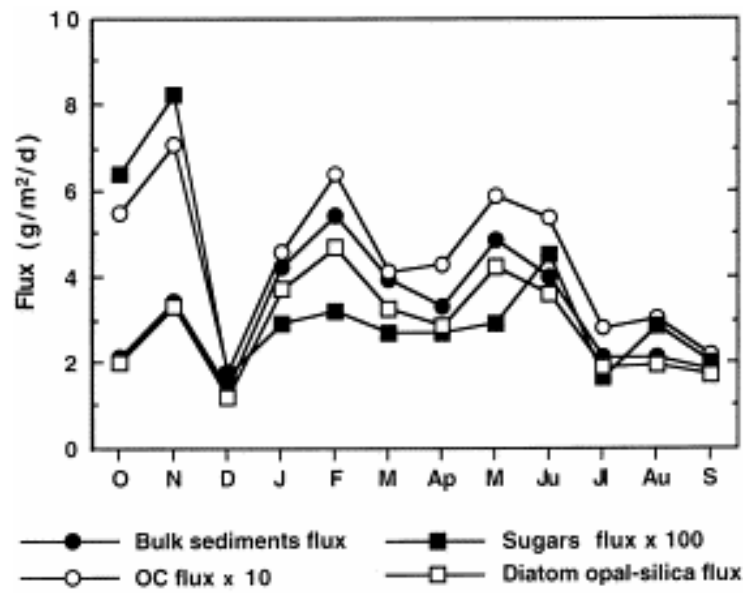

Fig. 1. Variations of bulk sediments, organic carbon (OC), sugars and diatom opal-silica fluxes in the epilimnion from October 1995 to September 1996.

In sediment-trap samples, the concentrations of all monosaccharides normalised to OC contents $\left(\mathrm{TCH}_{2} \mathrm{O}\right)$, are generally greater than $4 \mathrm{mg}$ carbohydrate/100 $\mathrm{mg} \mathrm{OC}$, as determined in the bottom sediment upper layer which represents at least 2 years of sedimentation (Fig. 2; 
Table 3). From January to May and in July 1996, the $\mathrm{TCH}_{2} \mathrm{O}$ concentrations remain rather low in all traps with an average value of $6.1 \mathrm{mg} / 100 \mathrm{mg} \mathrm{OC}$ whereas high $\mathrm{TC \textrm {H } _ { 2 } \mathrm { O }}$ concentrations are measured in June and from August to December. In contrast to the rest of the year, homogeneous $\mathrm{TCH}_{2} \mathrm{O}$ concentrations of 11.6 and of $9.5 \mathrm{mg} / 100 \mathrm{mg}$ OC were measured in the three traps, in November and December, respectively. Conversely, during summer, higher monosaccharide concentrations are found in the hypolimnion (traps at 10 and $14 \mathrm{~m}$ ) than in the epilimnion (trap at $5 \mathrm{~m}$ ) (Table 2). During the same period, or more exactly from June to October, the $\mathrm{TCH}_{2} \mathrm{O}$ concentrations increase from 8.5 to $11.6 \mathrm{mg} / 100 \mathrm{mg} \mathrm{OC}$ in the epilimnion.

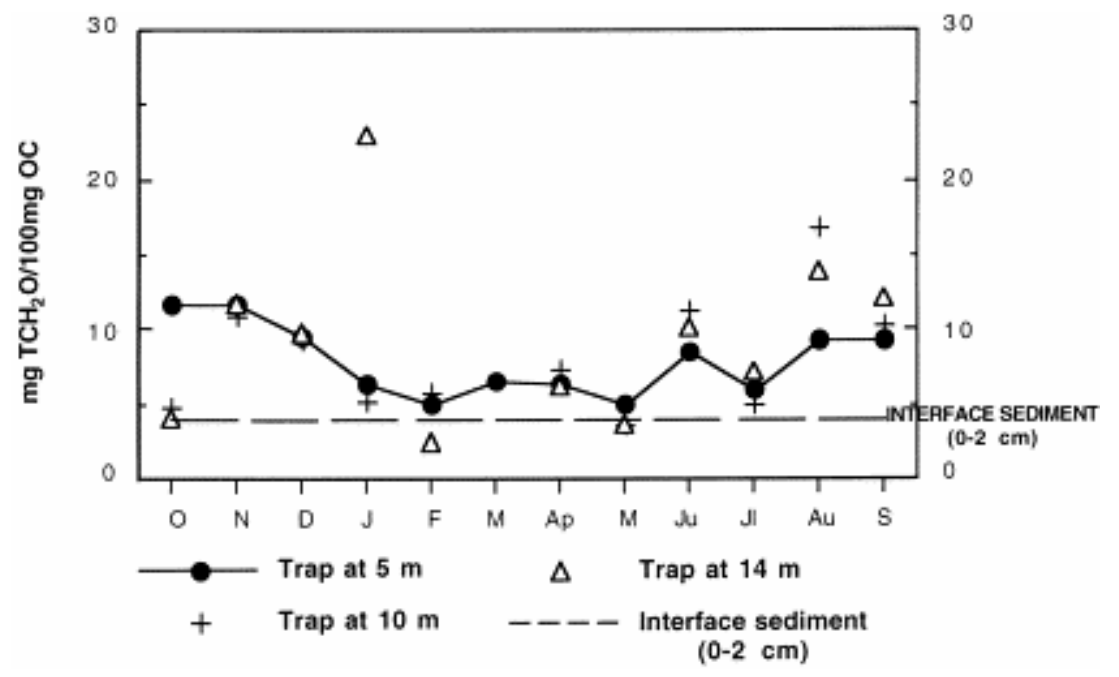

Fig. 2. Monthly variations of carbohydrate concentrations $\left(\mathrm{mgTCH}_{2} \mathrm{O} / 100 \mathrm{mg} \mathrm{OC}\right)$ in sinking particles collected at 5, 10 and $14 \mathrm{~m}$ water depth. Comparison with sugar concentration at the water-sediment interface $(0-2 \mathrm{~cm}$ core interval).

In general, weight percentages of individual neutral sugars in all sediment-trap samples are dominated by rhamnose $(40-50 \%)$, followed by glucose (25-30\%), fucose (10-20\%), xylose $(8-10 \%)$, mannose $(5-8 \%)$, galactose $(2-3 \%)$ and arabinose $(2-3 \%)$. Ribose is present at low concentrations and often below the detection limit (Table 2). Only seven of the 36 samples record a different sugar composition ( Table 2). Four of these samples which were collected in the shallow trap (trap at $5 \mathrm{~m}$ ) in October, February, July and September, mainly contain noncellulosic glucose, while three other samples, which were collected in the deepest traps at 10 $\mathrm{m}$ in January and at $14 \mathrm{~m}$ in April and May, have cellulosic glucose and xylose as dominant sugars.

Overall, the main compositional change in the water column is observed in summer, especially in June and September. Then, the fluxes of arabinose, rhamnose and fucose increase with depth whereas those of glucose, mannose, galactose and ribose decrease, sometimes until total disappearance (e.g. mannose and galactose in September; Table 2). As shown in Fig. 3 for the three major sugars, this seasonal trend is particularly well marked in September with a threefold increase of the fluxes of rhamnose and fucose from 5 to $14 \mathrm{~m}$ depth and with a simultaneous stronger decrease in the flux of glucose. During summer, a significant positive linear correlation is seen between the fluxes of rhamnose and fucose: $R_{\text {Rham-Fuc }}=0.94$ for $n=12$ (Fig. 4 ). 


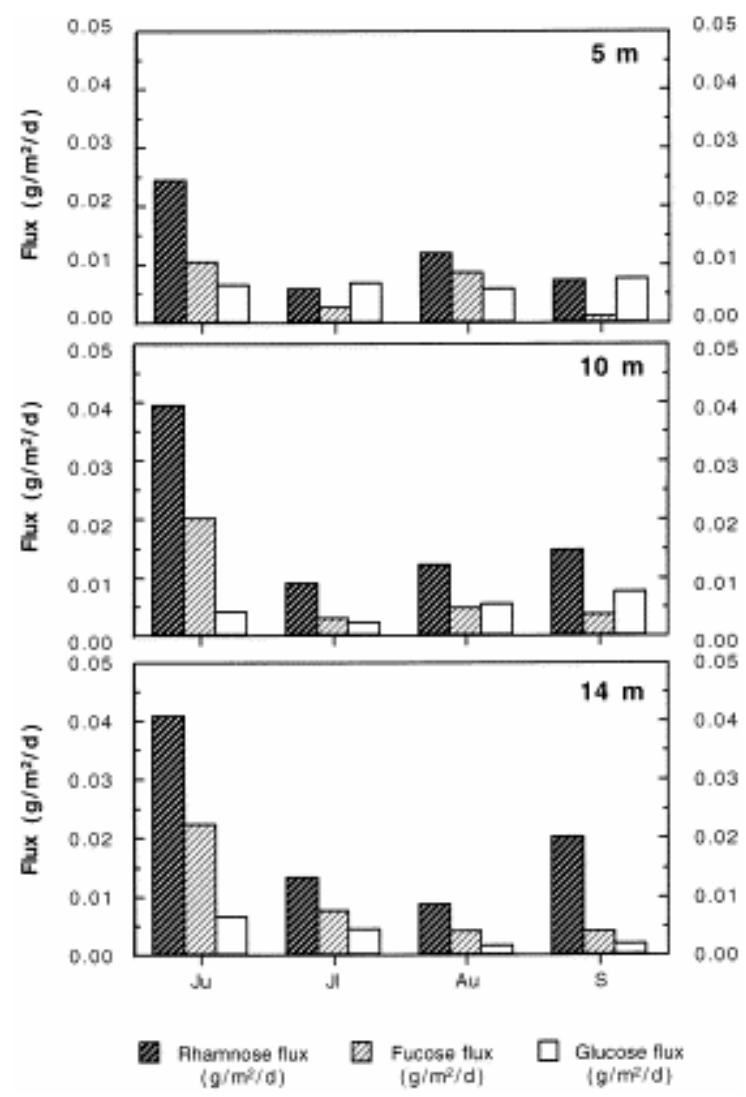

Fig. 3. Variations in rhamnose, fucose and glucose fluxes in sinking particles collected at 5, 10 and $14 \mathrm{~m}$ water depth, in summer (from June 1996 to September 1996).

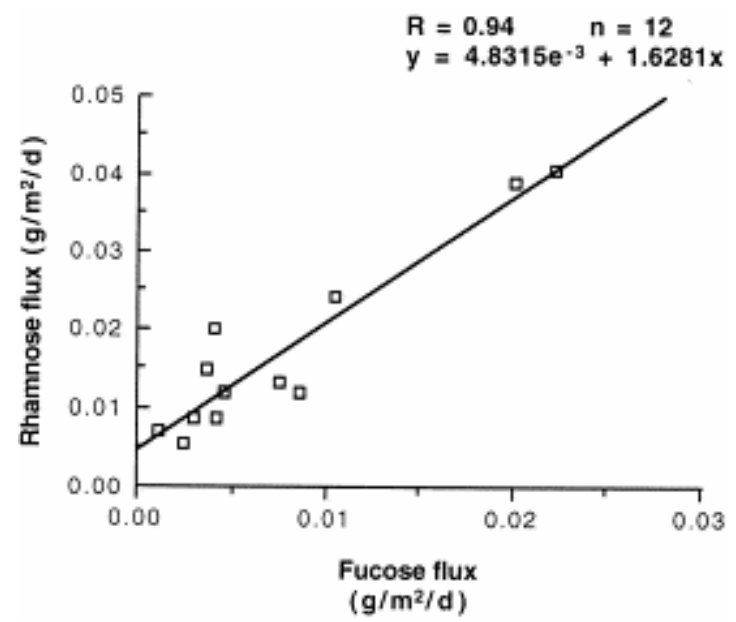

Fig. 4. Correlation between rhamnose and fucose fluxes in three traps during summer (from June 1996 to September 1996).

\subsection{Core sediments}

OC values first decrease sharply from more than $11.5 \%$ at the top of the core to less than $8 \%$ in the immediate underlying two-centimetre thick layer and to $6.5 \%$ in the following twocentimetre thick layer (at $5 \mathrm{~cm}$ depth). This downward trend continues more smoothly to reach values of ca. $4 \%$ OC at about $40 \mathrm{~cm}$ depth (Table 3). The total neutral carbohydrate concentration exhibits a similar downcore profile with a value of $4.6 \mathrm{mg} / \mathrm{g}$ (dry weight basis) 
at the water-sediment interface, followed by $3 \mathrm{mg} / \mathrm{g}$ at $5 \mathrm{~cm}$ depth and only $1.2 \mathrm{mg} / \mathrm{g}$ at $43 \mathrm{~cm}$ depth ( Fig. 5). These compound concentrations indicate that only $0.9-2.1 \%$ of the sediment organic carbon is from carbohydrates. These values compare unfavourably with the $17 \%$ amino-acid carbon found by Albéric et al. (1996) in the upper sediment level $(0-5 \mathrm{~cm})$.

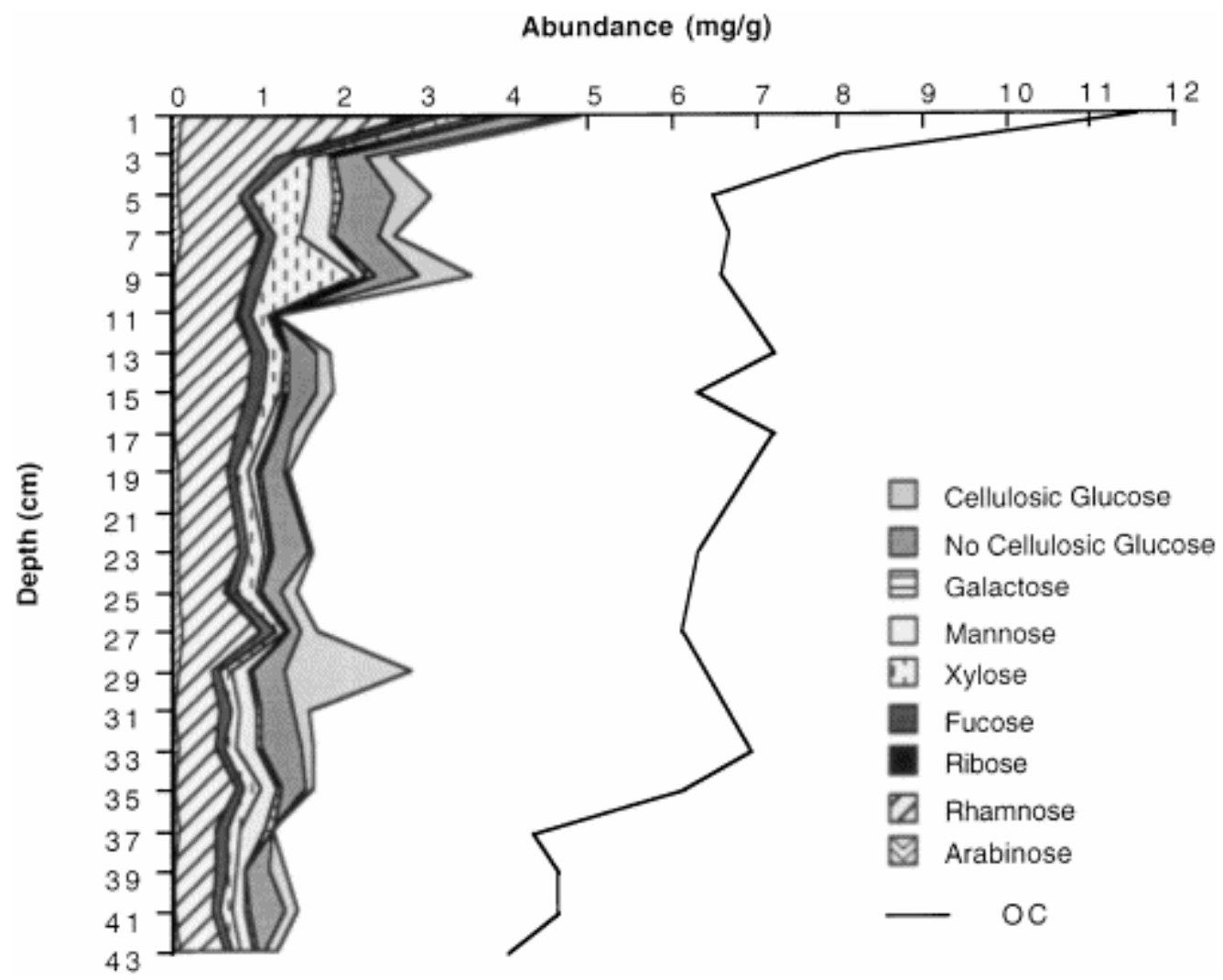

Fig. 5. Abundance $(\mathrm{mg} / \mathrm{g})$ of individual sugars and OC content in core sediment samples.

The average carbohydrate composition of the bottom sediments is close to that of the sediment trap samples except for fucose which is slightly less abundant. Rhamnose is always the dominant monosaccharide (40-50\%), followed by glucose $(25-30 \%)$, xylose $(10 \%)$, fucose $(8-10 \%)$, mannose $(5-8 \%)$, galactose $(2-4 \%)$ and arabinose $(1-3 \%)$, with ribose often below the detection limit.

The concentration of most individual monosaccharides shows the same decreasing trend with depth, except for rhamnose which decreased more sharply than the other compounds in the top $5 \mathrm{~cm}$. The rather smooth decrease of the concentrations of xylose and cellulosic glucose is interrupted by anomalously high amounts of one or both these compounds at 5,9 and $29 \mathrm{~cm}$ depth (Fig. 5 and Table 3).

\section{Discussion}

\subsection{Carbohydrate flux in the water column}

The sharp maximum of particulate material, diatom-silica, OC and total carbohydrates observed in the trap at $5 \mathrm{~m}$ in November as well as the high fluxes of all these components also observed in winter and spring (i.e. from January to June) in the same trap (Fig. 1), 
correspond closely to the settling of diatoms which constitute the greatest part of the phytoplanktonic production in lake Aydat (Aleya and Devaux, 1989). If the diatoms dominate the phytoplanktonic production during spring, they give way in August to cyanobacteria, themselves dominated by the genus Microcystis and Anabaena (Amblard et al, 1988). In November, during lake overturn ( Poulin, 1997), the fluxes of organic carbon and sugars reach their maximum ( Table 2): $0.71 \mathrm{~g} / \mathrm{m}^{2} / \mathrm{d}$ at $5 \mathrm{~m}$ to $1.02 \mathrm{~g} / \mathrm{m}^{2} / \mathrm{d}$ at $14 \mathrm{~m}$ for OC and $0.082 \mathrm{~g} / \mathrm{m}^{2} / \mathrm{d}$ at $5 \mathrm{~m}$ to $0.118 \mathrm{~g} / \mathrm{m}^{2} / \mathrm{d}$ at $14 \mathrm{~m}$ for total carbohydrates. These high values can be explained by the well-known flocculation of organic and mineral matter on iron oxyhydroxides (Sigg et al., 1992). As a matter of fact, in seasonally anoxic lakes, iron oxyhydroxides are formed when $\mathrm{Fe}^{2+}$ species, that accumulated in the anoxic hypolimnion during the period of water stratification, are overturned in the water column and oxidised. Authigenic oxy-hydroxides of iron have an important specific surface that permits the adhesion and flocculation of most of the organic compounds (Tipping; Tipping and Hamilton). This process is favoured by divalent cations such as magnesium and calcium which reduce the negative repulsion forces between particles ( Fattom and Shilo, 1984). The efficiency of this process results in an almost total purification of the water body, as demonstrated by the very low flux values determined in December ( Fig. 1).

$\mathrm{TCH}_{2} \mathrm{O}$ values provide an indication of the reactivity of sugars relative to bulk OC (Fig. 2). Thus, the increase in $\mathrm{TCH}_{2} \mathrm{O}$ concentrations, observed in the epilimnion from June to September, suggests a progressive enrichment of settling particles in sugar and maybe other organic compounds. As previously observed by Hick et al. (1994) in Lake Itasca (Minnesota, USA), this trend is consistent with the simultaneous increase in the density of the phytoplankton population in the summer ( Amblard et al., 1988).

If one considers the neutral carbohydrate data in the deepest traps (10 and $14 \mathrm{~m})$, one notices that the total fluxes determined in October, January, May and July at $10 \mathrm{~m}$, and in October and February at $14 \mathrm{~m}$ do not agree very well with OC contents (Table 2). All the corresponding samples are also characterised by $\mathrm{TCH}_{2} \mathrm{O}$ concentrations lower than those measured in the trap at $5 \mathrm{~m}$ over the same periods, and even less than those determined in the top 0-2 cm sediment core interval (Fig. 3). These samples also generally present (i) higher sedimentary fluxes than those determined in the epilimnion for the same month, and (ii) higher concentration of xylose and/or cellulosic glucose ( Table 2). The abundance of these two compounds, characteristic of the structural polysaccharides of higher plants ( Timmell and Sjostrom), suggests large inputs of vascular plant remains from the watershed. This allochthonous material was most likely brought into the lake by the Veyre river, the flow of which penetrates the water body at $5 \mathrm{~m}$ depth ( Poulin, 1997).

\subsection{Source of carbohydrates}

During summer (from June to October), except for samples influenced by terrigenous inputs (especially in July and in October), the $\mathrm{TCH}_{2} \mathrm{O}$ concentrations (Fig. 2) increase from the epilimnion to the hypolimnion: they then reach their maximum values in the range of 10.1 to $16.8 \mathrm{mg} / 100 \mathrm{mg}$ OC. This increase of carbohydrate in sinking particles might indicate abundant organic production in the anoxic hypolimnion, and thus from bacteria. The high proportions of rhamnose in trap samples, and the increase of the flux of this compound with increasing water depth in addition with those of fucose, suggest a non-vascular plant source, that is a microbial origin for both compounds ( Fig. 3). Fucose is often mentioned as a storage polysaccharide in phytoplankton ( Percifal and Cowie) or as a main component of diatoms ( Hecky et al., 1973). However, the association of fucose with rhamnose strongly suggests a 
bacterial origin for both these deoxyhexoses ( Barker; Boon et al., 1983; Bhosle and Hicks). Hicks et al. (1994), who performed sugar analyses on different organic materials (vascular plants, zooplankton, phytoplankton and bacteria), observed that only bacteria contained abundant proportions of rhamnose and fucose, e.g. $25.8-44.9 \%$ of the former and $4.4-18.1 \%$ of the latter in Pseudomonas fluorescens and Azotobacter chrococcum, respectively. In addition Coulobacter crecentus contained up to $60.6 \%$ rhamnose but no fucose. It has also long been known that Pseudomonas aeruginosa is able to synthesize important quantities ( $\geqslant$ $3.16 \mathrm{~g} / \mathrm{l})$ of an extracellular glycolipid consisting of two moles of 1- $\beta$-hydroxydecanoic and two moles of rhamnose (Jarvis and Hauser). Similar compositions were found in trap samples from lake Aydat where the relative amounts of rhamnose and fucose were in the range of $34.1-59.5 \%$ and of $5.2-27.8 \%$, respectively. The association of these compounds is also striking, especially in summer where their flux values are highly correlated: $R_{\text {Rham-Fuc }}=0.94$ (Fig. 4). By analogy with previous observations, we suggest that rhamnose and fucose are most probably derived from heterotrophic bacteria capable of thriving in anoxic waters at the expense of cyanobacteria which proliferate in the epilimnion during summer ( Amblard, 1992). The apparent preservation of microbial sugars might have been favoured by a preferential consumption of proteins rather than sugars by the microbial community, during cyanobacterial decay under anoxic conditions ( Harvey et al., 1995). This interpretation is supported by the simultaneous decrease in glucose, with depth, since this ubiquitous compound is common in cyanobacteria ( Weckesser and Malam Issa, 1999) and in diatoms ( Meeuse; Bolter and Tanoue). In these latter organisms, glucose occurs in chrysolaminarin $\alpha$ B-1-3 glucan, a storage polysaccharide that is easily removed by aquatic biota in sinking diatoms ( Handa; Hitchcock; Liebezeit and Bhosle). Galactose and mannose also decrease with water depth and might similarly be components of storage polymers susceptible to degradation during settling. Similar observations made on other aquatic environments, oceans or rivers, were also interpreted as symptomatic of the degradation of autochthonous material in the water column ( Hamilton; Bhosle; Hedges and Hernes).

\section{Preservation and stability of carbohydrates}

The concentrations of all monosaccharides normalised to $\mathrm{OC}$ contents ( $\mathrm{TC} \mathrm{CH}_{2} \mathrm{O}$ ) (Fig. 2) are generally much higher in the trap samples than in the $0-2 \mathrm{~cm}$ core sediment interval. This decrease of total $\left(\mathrm{TCH}_{2} \mathrm{O}\right.$ ) and individual compound values continues in the bottom sediments (Table 3), especially in the upper $5 \mathrm{~cm}$. Similar observations made in various aquatic environments, were interpreted as the result of degradation of organic material at the water-sediment interface ( Cornett; Hedges and Hicks). The occurrence of high proportions of rhamnose in trap and core sediment samples denotes the abundant production of this sugar by bacteria in the water column and especially at the sediment surface. Its efficient removal in the top $5 \mathrm{~cm}$ sediment interval is most certainly realised by different genera of bacteria. Despite this evolution in the upper part of the sediment core, the average sugar composition of the core sediment is similar to that of the trap samples. However, glucose and fucose concentrations decrease substantially between the deepest trap $(14 \mathrm{~m})$ and the $0-2 \mathrm{~cm}$ sediment core interval. For example, in December, the relative concentration of these two compounds decreases from 25 to $14 \%$ and from 10 to $7 \%$, respectively. The corresponding evolution of these two sugars suggests that they have the same origin. The assumption that glucose originates from primary producers like diatoms (see above) implies that fucose might also, at least partly, originate from such organisms, even if it is mainly associated with bacteria. In such conditions, the decrease of glucose and fucose at or near the water-sediment interface might express a preferentially removal of phytoplanktonic organic compounds. In addition to primary material consumption by heterotrophic bacteria, this removal can partly be 
caused by the producers themselves. As a matter of fact, when the latter have sunk alive to the bottom of the lake, they can use their storage components during their time of survival. The survival of at least $50 \%$ of these organisms at depth in the water column (e.g. $-30 \mathrm{~m}$ ) has been proven by ATP measurements in lake Pavin ( Amblard and Bourdier, 1990). Intact bacterial cells can also contribute substantially to the organic carbon pool, particularly during periods where microbial activity is greatest ( Harvey and Macko, 1997). The higher proportions of cellulosic glucose, xylose, mannose, galactose and arabinose in core sediment samples than in the trap samples suggest that they are more refractory to biodegradation than the previously mentioned compounds. Xylose and cellulosic glucose are diagnostic of allochthonous inputs of cellulose and hemicellulose from the watershed. In addition to the well-known intrinsic resistance of these two polymers to bacterial attack ( Hedges and Tanoue), they might also have been protected by some external means (e.g. by adsorption onto clay minerals; Oades, 1995). The abundant proportions of xylose and cellulosic glucose at 5 and $9 \mathrm{~cm}$ depth, suggests the presence of some vascular plant debris at these levels. This hypothesis is strongly supported by the fact that a notable part of the xylose found at these levels (i.e. 69 and $89 \%$, respectively) was released with cellulosic glucose, during the second acid hydrolysis, after soaking with concentrated $\mathrm{HCl}$.

\section{Conclusion}

The neutral carbohydrate compositions of trap and core sediment samples allow us to formulate the follow major conclusions: in lake Aydat, the organic matter originates principally from non-vascular plants. The amounts of sugars increase progressively: (i) in the epilimnion during summer, until phytoplankton production reaches its maximum and (ii) in the hypolimnion as a result of high bacterial production.

Secondary organic inputs originate from vascular plant which are characterised by their content of xylose and cellulosic glucose. From time to time, rather high proportions of these two compounds in the deepest traps denote lateral inputs of allochthonous organic matter contributed by the river Veyre. The occurrence of such events is also recorded at some levels in the sediment core.

The abundance of rhamnose in traps and core sediments and the increase of sugar contents with depth in the water column, during stratification, suggest that the monosaccharide abundance and composition is strongly related to microbial production. There is, possibly, also some sugar preservation during anoxic cyanobacterial decay due to preferential microbial consumption of other biochemical compounds e.g. proteins. A notable part of the primary sugars that are not mineralised during settling are degraded at the water-sediment interface by heterotrophic bacteria produced in situ, perhaps also by organisms produced in the water column that have sunk alive to the bottom of the lake. Under these conditions, in contrast to fatty acids which are deposited, unaltered, to the bottom of the lake (Maurin and Bourdier, unpublished data), the neutral sugar composition does not solely reflect the primary planktonic production but also the activity of the microflora and the mineralization of organic matter.

Even then, in conditions which favour organic matter accumulation, i.e. high primary production and reducing conditions, efficient sugar consumption by the microbiota prevents the carbohydrates from contributing significantly to the preserved organic matter. However, these polymers, present in relatively low amounts in sediments are a useful tool for the study of biological and physico-chemical processes that occur in the aquatic environment. 


\section{Acknowledgements}

This research was supported by the DBT INSU program "Interface eau-sédiment" managed by Professor Gil Michard. The authors wish to thank Gil Michard, Gérard Sarazin, Didier Jézéquel and Eric Viollier from the Laboratoire de Géochimie des Eaux (Université Paris VII) for carrying out the sediment trap deployment and for collaboration in the field.

\section{References}

Albéric, P., Sarazin, G. and Michard, G., 1996. Combined amino acid speciation in lake sediment and porewater (Aydat lake, France). Aquatic Geochemistry 2, pp. 29-49.

Aleya, L. and Devaux, J., 1989. Intérêt et signification écophysiologique de l'estimation de la biomasse et de l'activité photosynthetique de diverse fractions de taille phytoplanctonique en milieu lacustre eutrophe. Journal des Sciences de l'Eau 2, pp. 353-372. Abstract-EMBASE |

Amblard, C., Adiwilaga, E.M. and Devaux, J., 1988. Nucléotides adenyliques et assimilation photosynthétique du phytoplancton dans deux lacs du Massif Central francais. International Revue der gesamten Hydrobiologie 73, pp. 191-211.

Amblard, G. and Bourdier, G., 1990. The spring bloom of the diatom Melosira italica subsp. subarctica in Lake Pavin : biochemical, energetic and metabolic aspects during sedimentation. Journal of Plankton Research 12, pp. 645-660.

Amblard, C., 1992. Seasonal periodicity in lacustrine phytoplankton and the theory of ecological succession. International Revue der gesamten Hydrobiologie 77, pp. 121-134.

Barker, S.A. and Somers, P.J., 1970. Bacterial and fungal polysaccharides. In: Pigman, W. and Horton, D., Editors, 1970. The Carbohydrates : Chemistry and Biochemistry, IIB, Academic Press, New York, pp. 569-587.

Bethge, O., Holmström, C. and Juhlin, S., 1966. Quantitative gas chromatography of mixtures of simple sugar. Svenk Papperstidning 69, pp. 60-63.

Bhosle, N.B., Sankaran, P.D. and Wagh, A.B., 1992. Monosassharides composition of suspended particles from the Bay of Bengal. Oceanologica Acta 15, pp. 279-286.

Bhosle, N.B. and Wagh, A.B., 1989. Particulate carbohydrates in the Arabian Sea. Oceanologica Acta 12, pp. 57-63.

Boon, J.J., Hines, H., Burlingame, A.L., Klok, J., Rijpstra, W.I.C., Leeuw, J.W.D., Edmunds, E.K., Eglinton, G., 1983. Organic geochemical studies of Solar Lake laminated cyanobacterial mats. In: Bjoroy M. et al. (Eds.), Advances in Organic Geochemistry 1981. John Wiley, pp. 207-227.

Bölter, M. and Dawson, R., 1982. Heterotrophic utilisation of biochemical compounds in Antartic waters. Netherland Journal of Sea Research 16, pp. 315-332. 
Bourdon, S. 1999. Approches micromorphologiques et moléculaires de la diagenése précoce de la matière organique dans une tourbe à Cypéracées en milieu tropical (Tritrivakely, Madagascar). Implications paléoenvironnementales. Thesis of Université d'Orléans.

Bourdon, S., Laggoun-Défarge, F., Disnar, J.R., Maman, O., Guillet, B., Derenne, S. and Largeau, C., 2000. Early diagenesis of organic matter from higher plants in a malagasy peaty marsh. Application to environmental reconstruction during the Sub-Atlantic. Organic Geochemistry 31, pp. 421-438.

Cornett, R.J. and Rigler, F.H., 1987. Decomposition of seston in the hypolimnion. Canadian Journal of Fish Aquatic Science 44, pp. 146-151.

Cowie, G.L. and Hedges, J.I., 1984. Carbohydrate sources in a coastal marine environment. Geochimica et Cosmochimica Acta 48, pp. 2075-2087.

Disnar, J.-R. and Trichet, J., 1980. Etude expérimentale de la fixation des métaux par un matériau sédimentaire actuel d'origine algaire-I. Isolement, purification et caractérisation de la matiere organique. Geochimica et Cosmochim. Acta 45, pp. 353-362.

Espitalié, J., Derro, G. and Marquis, F., 1985. La pyrolyse Rock-Eval et ses applications. Revue de l'Institut Français du Pétrole 40, pp. 563-579.

Fattom, A., Shilo, M. 1984 Hydrophobicity as an adhesion mechanism of benthic cyanobacteria. Applied and Environmental Microbiology, 135-143.

Hamilton, S.E. and Hedges, J.I., 1988. The comparative geochemistries of lignins and carbohydrates in a anoxic fjord. Geochimica et Cosmochimica Acta 52, pp. 129-142.

Hamilton-Taylor, J., Davisson, W. and Morfett, K., 1996. The biogeochemical cycling of Zn, $\mathrm{Cu}, \mathrm{Fe}, \mathrm{Mn}$, and dissolved organic $\mathrm{C}$ in a seasonally anoxic lake. Limnology and Oceanography 41, pp. 408-418.

Handa, N., 1969. Carbohydrate metabolism in the marine diatom Skeletonema costatum. Marine Biology 4, pp. 208-214.

Harvey, H.R., Tuttle, J.H. and Bell, J.T., 1995. Kinetics of phytoplankton decay during simulated sedimentation: Changes in biochemical composition and microbial activity under oxic and anoxic conditions. Geochimica et Cosmochimica Acta 59, pp. 3367-3377.

Harvey, H.R. and Macko, S.A., 1997. Catalysts or contributors? Tracking bacterial mediation of early diagenesis in the marine water column. Organic Geochemistry 26, pp. 531-544.

Hauser, G. and Karnovsky, M., 1954. Studies on the production of glycolipids by Pseudomonas aeruginosa. Journal of Bacteriology 68, pp. 645-648.

Hecky, R.E., Mopper, K., Kilham, P. and Degens, E.T., 1973. The amino acid and sugar composition of diatom cell-walls. Marine Biology 19, pp. 323-331

Hedges, J.I., Clark, W.A. and Cowie, G.L., 1988. Organic matter sources to the water column and surficial sediments of a marine bay. Limnology and Oceanography 33, pp. 1116-1136. 
Hedges, J.I., Cowie, G.L., Ertel, J.R., Barbour, R.J. and Hatcher, P.G., 1985. Degradation of carbohydrates and lignins in buried woods. Geochimica et Cosmochimica Acta 49, pp. 701711. Abstract

Hedges, J.I., Cowie, G.L., Richey, J.E., Quay, P.D., Benner, R., Strom, M. and Forsberg, B.R., 1994. Origins and processing of organic matter in the Amazon River as indicated by carbohydrates and amino acids. Limnology and Oceanography 39, pp. 743-761.

Hernes, P.J., Hedges, J.I., Peterson, M.L., Wakeham, S.G. and Lee, C., 1996. Neutral carbohydrates geochemistry of particulate material in the centra equatorial Pacific. Deep-Sea Research 43, pp. 1181-1204.

Hicks, R.A., Owen, C.J. and Aas, P., 1994. Deposition, resuspension, and decomposition of particulate organic matter in the sediments of Lake Itasca, Minnesota, USA. Hydrobiologia 284, pp. 79-91.

Hitchcock, G.L., 1977. The concentration of particulate carbohydrates in a region of the West Africa upwelling zone dsuring March 1974. Deep Sea Research 24, pp. 83-93.

Jarvis, F.G. and Johnson, M.J., 1949. A glyco-lipid produced by Pseudomonas aeruginosa. Journal of the American Chemical Society 71, pp. 4124-4126.

Liebezeit, G., 1984. Particulate carbohydrate in relation to phytoplankton in the eutrophic zone of the Bransfield strait. Polar Biology 2, pp. 225-228.

Malam Issa, O., 1999. Etude du rôle des crôutes microbiotiques dans les sols de deux écosystèmes sahéliens (jachères et brousse tigrée) au Niger: micromorphologie, propriétés physiques et biogéochimiques. Thesis of Université d'Orléans.

Meeuse, B.J.D., 1962. Storage products. In: Lewin, R.A., Editor, , 1962. Physiology and Biochemistry of Algae, Academic Press, New-York and London, pp. 293-299.

Meyers, P.A., Ishiwatari, R., 1995. Organic matter accumulation records in lake sediments. In: Lerman, A., Imboden, D., Gat, J. (Eds.), Physics and Chemistry of Lakes, pp. 279-328.

Michard, G., Albéric, P., Jézéquel, D., Ogier, S., Sarazin, G., in press. Annual budget of chemical elements in an eutrophic lake, Aydat lake, France. Water Research.

Modzeleski, J.E. and Laurie, W.A., 1971. Carbohydrates from Santa Barbara Bassin: gas chromato-mass sopectro analysis of trimethylsilsyl derivatives. Geochimica et Cosmochimica Acta 35, pp. 825-838.

Moers, M.E.C., Jones, D.M., Eakin, P.A., Fallick, A.E., Griffiths, H. and Larter, S.R., 1993. Carbohydrate diagenesis in hypersaline environments: application of GC-IRMS to the stable isotope analysis of derivatized saccharides from surficial and buried sediments. Organic Geochemistry 20, pp. 927-933.

Oades, J.M., 1995. An overview of processes affecting the cycling of organic carbon in soils. In: Zepp, R and Sontag, Ch, Editors, 1995. The Role of Non-living Organic Matter in the Earth's Carbon Cycle, J. Wiley and Sons, New York, pp. 293-303. 
Oades, J.M., Kirkman, M.A. Wagner, G.H. 1970. The use of gas-liquid chromatography for the determination of sugars extracted from soils by sulfuric acid. Soil Sciences Society America Procedings, 230-235.

Ogier, S., 1999. Diagenése précoce en domaine lacustre: étude des composés minéraux et organiques des sédiments récents (trappes et carottes) du lac d'Aydat (Puy de Dôme, France). Thesis of Université d'Orléans.

Parsons, T.R., Takahashi, M. and Hargrave, B., 1984. Biological Oceanographic Processes. , Pergamon Press, Oxford.

Percifal, A., 1970. Algal carbohydrates. In: Pigman, W. and Horton, D., Editors, 1970. The Carbohydrates: Chemistry and Biochemistry, IIB, Academic Press, London, pp. 537-568.

Poulin, M., 1997. Rapport d'avancement Projet INSU Reactivite de l'Interface Eau-Sediment.

Sarazin, G. and Devaux, J., 1991. Diagenese precoce de la matiere organique dans la colonne d'eau et le sediment d'un lac eutrophe: le lac d'Aydat (Puy-de-Dome). Oceanis 17, pp. 533560 .

Sarazin, G., Gaillard, J.F., Philippe, L. and Rabouilles, C., 1995. Organic matter mineralization in the pore water of eutrophic lake (Aydat Lake, Puy de Dôme, France). Hydrobiologia 285, pp. 1-25.

Sarazin, G., Michard, G., AlGharib, I. and Bernat, M., 1992. Sedimentation rate and early diagenesis of particulate organic nitrogen and carbon in Aydat Lake (Puy de Dôme, France). Chemical Geology 98, pp. 307-316.

Sigg, L., Stumm, W., Behra, P. 1992. Chimie des Milieux Aquatiques. Chimie des Eaux Naturelles et des Interfaces dans l'Environnement. Masson Pub, Paris, p. 391.

Sigleo, A., 1996. Biochemical components in suspended particles and colloids: carbohydrates in the Potomac and Patuxen estuaries. Organic Geochemistry 24, pp. 83-93.

Sjostrom, E., 1981. Wood Chemistry, Fundamentals and Applications., Academic Press, London.

Stefanova, M. and Disnar, J.R., 2000. Composition and early diagenesis of fatty acids in lacustrine sediments, lake Aydat (France). Organic Geochemistry 31, pp. 41-55.

Tanoue, E. and Handa, N., 1987. Monosaccharides composition of marine particles and sediments from the Bering Sea and the northern North Pacific. Oceanologica Acta 10, pp. 9199.

Timmell, 1957. Carbohydrate composition of ten North American species of wood. Tappi 40, pp. 568-572.

Tipping, E., Woof, C. and Cooke, D., 1981. Iron oxide from a seasonally anoxic lake. Geochimica et Cosmochimica Acta 45, pp. 1411-1419. Tipping, E. and Woof, C., 1983. 
Elevated concentration of humic substances in a seasonally anoxic hypolimnion: evidence for co-accumulation with iron. Archiv für Hydrobiologie 98, pp. 137-145.

Vallentyne, J.R., 1963. Geochemistry of carbohydrates. In: Breger, I.A. (Ed.), Organic Geochemistry, Oxford, pp. 456-502.

Weckesser, J. and Drews, G., 1979. Lipopolysaccharides of photosynthetic prokaryotes. Annual Review of Microbiology 33, pp. 215-239.

Wicks, R.J., Moran, M.A., Pittman, L.J., Hodson, R.E., 1991. Carbohydrates signatures of aquatic macrophytes and their dissolved degradation products as determined by sensitive high-performance ion chromatography method. Applied and Environmental Microbiology, November, 3135-3143. 